\title{
SPECIFIC HIGH-INTENSITY INTERVALTRAINING FOR JIU-JITSU
}

\section{${ }^{1}$ Eduardo dos Santos Figueira Rodrigues, ${ }^{2}$ Bruno Cezar Barbosa Silva and ${ }^{3}$ Leandro Paiva}

1Doctor's Degree Sports Science by Atlantic International University - AIU - USA, Coach and Member of the Technical Committee for the development of the martial arts training program in the Armed Forces of the United Arab Emirates, UAE

2Degree in Logistics and Master'sDegree in Sports Sciences from the University of Trás-os-Montes and Alto Douro UTAD- Portugal, Jiu-jitsu Coach of the UAE Armed Forces, UAE

${ }^{3}$ Researcher and writer supported by Amazonas State Research Foundation - FAPEAM, Master's in Social Anthropology from the Federal University of Amazonas. Graduated in Physical Education from the Federal University of the State of Rio de Janeiro

\section{ARTICLE INFO}

\section{Article History:}

Received $28^{\text {th }}$ August, 2020

Received in revised form

$14^{\text {th }}$ September, 2020

Accepted $22^{\text {nd }}$ October, 2020

Published online $30^{\text {th }}$ November, 2020

\section{Key Words:}

Brazilian Jiu-jitsu; Performance evaluation; High-intensity interval training; Combat Sport; Time motion analysis.

*Corresponding author:

Eduardo dos Santos Figueira Rodrigues

\begin{abstract}
Known as HIIT (High-Intensity Interval Training) or high-intensity interval training is at the top of current training. This type of training allows athletes to exercise longer in high intensity and not the other way around. The main objective of this work is to provide a tool for physical education professionals and trainers to evaluate their jiu-jitsu fighters specifically through an adaptation of interval training to jiu-jitsu, and can also obtain parameters through a targeted methodology, such as the fighter's specific endurance index test. The methodology also consists of promoting during the test, active recovery and a high cadence in the executions of movements, this recovery will also promote a higher oxygen consumption with close effort/pause, being considered as short HIIT, with values in the subjective scale of effort perception of 6 to 20 , corresponding to high-intensity interval training. According to all the results obtained we can verify that it is an evaluation tool that complies with the requirements of an activity characterized as short intensity interval training, with active recovery, so it has higher caloric expenditure in the training section, as well as oxygen consumption and even a higher average heart rate in training because the subjective perception of mean effort among the subjects tested was 16 on the Borg scale. It is concluded that this proposal meets the initial objectives and will, in addition, this concept can be used for any type of physical activity and various types of sports gestures, thus being an excellent tool for teachers and technicians, and can also be used as part of a structure of physical preparation for combat modalities in several specific phases of training.
\end{abstract}

Copyright (C) 2020, Eduardo dos Santos Figueira Rodrigues et al. This is an open access article distributed under the Creative Commons Attribution License, which permits unrestricted use, distribution, and reproduction in any medium, provided the original work is properly cited.

Citation: Eduardo dos Santos Figueira Rodrigues, Bruno Cezar Barbosa Silva and Leandro Paiva. "Specific high-intensity intervaltraining for Jiu-JITSU”, International Journal of Development Research, 10, (11), 42047-42057.

\section{INTRODUCTION}

Known as HIIT (High-Intensity Interval Training) is at the top of current training. This type of training allows athletes to exercise longer in high intensity and not the other way around. It's not just a short-term workout with high intensity, as some coaches tend to exemplify, as HIIT goes far beyond that. The main objective of this work is to provide a tool so that physical education professionals and trainers can evaluate their jiu-jitsu fighters specifically through an adaptation of interval training to jiu-jitsu, and can also obtain parameters through a targeted methodology, such as the fighter's specific endurance index test.
This work aims to correlate high-intensity training with the proposal of muscle fatigue test with specific Jiu-jitsu movements. Despite having directed the test to the sport of grab combat as is jiu-jitsu, this methodology can go beyond that, moreover, because each coach having prior knowledge of his modality can through this methodology, develop their parameters of analysis according to the specific temporality that is desired, as well as the relevant sports gestures, where it is intended to increase training in search of improvement, which should be constant, because the evolution of methods and parameters goes in great strides, and all the tools that can contribute to the athlete gain improvement in efficiency and 
effectiveness in the execution of movements, can make a difference. A stronger athlete, tougher, faster and still performing the moves to perfection, will certainly have more chances to succeed in the challenges that await him, so it is necessary a continuous evaluation of the results. Observation and an in-depth study, done in detail, on the type of combat sport that will be worked, are fundamental since each has its motor gestures and its characteristics of energy demand, which must be in agreement because the specificity of training can make a difference.

GENERAL OBJECTIVES: Present a tool to evaluate the fighter's specific resistance index, in addition to correlating temporality, specific movements to high-intensity interval exercises, suggesting that it also has the benefits of interval training and its energetic characteristic, but with the advantage of movements being directed specifically to jiu-jitsu.

SPECIFIC OBJECTIVE: Calculate the specific resistance index of the fighter, offering an evaluation tool where in addition to observation in improving training, the coach can implement other tools such as heart rate controls before, during and after each evaluation and also control the absolute number of repetitions, thus being able to observe improvements in anaerobic capacity, improvements in cardiovascular efficiency, speed and efficiency in the execution of techniques.Also with regard to the objective, I intend to offer a tool that does not necessarily perform the same exercises that were used in this work, the coach through this tool can and should have the freedom to create their movements, but maintaining a configuration similar to interval training, because it is what is closest to the combat sports that have intermittent efforts and with this, the teacher can use in various types of exercises and combinations according to the technical proposal to be worked, that is, a universal tool, which provides a technical and physical work at the same time, but with parameters of measurement and control of data where it can evaluate the evolution. Another very interesting factor regarding this work is that it can also be used for athletes and fighters who are not yet at a high-performance level, provided that the sports gestures are suitable for the level of training that is their group.

\section{EXPECTED RESULTS}

It is expected that this study will be introduced into the academic environment an efficient muscle fatigue control tool for jiu-jitsu fighters. In addition to being able to be used as high-intensity interval training with high values on the Borg scale. This tool should provide technical and physical work at the same time, however, with parameters of measurement and control of data, where it is possible to evaluate the evolution both in the physical part, as well as execution of movements with greater speed, seeking greater technical efficiency in the execution of the sports gesture. The academic environment, physical activities and physical preparations in general, still lack specific methodologies for the day-to-day of the coach, I understand that technology such as video analysis for comparison and measurement of results, is a methodology with greater precision, but this tool is expected to practical answers that can be combined with feedback from comparative videos of the training, for an evaluation regarding athletes who crave high performance, where more detailed adjustment can make a difference in the final result of planning. I hope that these results can be compared even with videos of participation in competitions.
Accompany the team throughout the process, it is essential, because the feedback after a competition is necessary so that we can make important adjustments, and at the same time, show your athlete, the hits and where he can improve, so that with this, you can extract as much of the possible performance, according to the characteristics of your fighter. One observation that I should emphasize is that the ideal would be, for physiologists and physical trainers, who intend to work with any other type of modality, who follow the same line of work, researching and raising information, and in the same way that I did with jiu-jitsu should be done with any sport of combat. Currently, there are studies for virtually all major combat sports modalities, and we have a vast research material, and this tool can certainly be adapted to each study because it is adaptable to different modalities and objectives. After all, it has a specific concept and not a specific form.

\section{METHODS}

Checking the specific fatigue threshold index, this means, according to researchers, that is "the ability to perform efficiently, the workload prescribed to overcome fatigue in predetermined conditions defined by a competitive sports activity". In other words, I will test directly, to what extent participants can maintain a high-intensity level of specific JiuJitsu movements for some time before they reach a state of neuromuscular fatigue. The term defined in the physiology of a temporary decrease in muscle performance is generally seen as a failure to maintain the expected strength or power over time. This submaximal physical effort with short breaks portrays exactly the environment of a Jiu-Jitsu fight.Indirectly, we are also testing the coordination, agility, endurance and isometric strength of the participants. Through this methodology, it is expected as the first hypothesis, to be able to evaluate the muscle fatigue index, and to obtain an excellent tool for specific evaluation of jiu-jitsu fighters, besides being used as interval training of high intensity specific for jiu-jitsu. A second remote hypothesis would be that the training does not present any relevant and comparative factor for the muscle fatigue index, and no correlation to a high-intensity interval training.

The methodology also consists of promoting during the test, active recovery and a high cadence in the execution of movements, this recovery will still promote a higher oxygen consumption with close effort/pause, being considered as short HIIT, with values in the subjective scale of perception of effort from 6 to 20, corresponding to high-intensity interval training. It will be observed as a priority, comparing the first SET in general, compared by age group, because the characteristics of the energy expenditures of the first SET are practically anaerobic and such characteristics are determinant in a fight.

PROCEDURE: A large group was separated to perform the test with 100 fighters who underwent the specific muscle fatigue test for jiu-jitsu, it was necessary a small training area of four square meters with a partner of the same weight category. All test participants must be wearing a Jiu-Jitsu kimono. To collect the data, a sheet of the scorecard must be printed earlier, and the calculation of the test result must be done with a calculator or Excel spreadsheet. Before the test, the participants will make a targeted and specific warm-up, being 20 seconds for each season (exercise), with continuous movements with an interval of 20 seconds between each exercise, thus performing the same movements that will be 
performed in the evaluation.However, this specific heating has a motor adaptation character for the test and elevation of the heartbeat, so it should be performed at moderate speed totaling 120 seconds of specific heating. The test consists of three different exercises; each exercise will be performed for 20 seconds (as many repetitions as test participants can perform during this period, maintaining the appropriate form), following an Isometric Active Recovery Timeof 20 seconds per exercise, which in the following table will always be the fourth photo of each movement.

RELATIONSHIP BETWEEN EFFORT / PAUSE: IART (Isometric Active Recovery Time), means rest interval time, relevant in this modality, with percentage values of $39.51 \%$. (No one is able to blow all the time). The IART refers to the temporal physical aspect related to the fact that, even at rest or recovery, the fighter continues to keeping handgrip strength (grip) in the opponent's gi(Paiva, Leandro (2015). Olhar clínico nas lutas, artes marciais e modalidades de combate. Rio de Janeiro: OMP.Pg 56).

The test will be performed in 3 (three) passages in the circuit, this concludes what we call SET, every 1 for 120 seconds and the same procedure will be repeated for SET 2 and SET 3 totaling 360 seconds or $6.0 \mathrm{~min}$. The maximum number of repetitions in each exercise and each SET will be analyzed, which will later be calculated using the muscle fatigue index formula.

The original table of the Paiva and Del Vecchio test of fatigue resistance index whereas evaluation parameters consist of:

- 0 to 0.5 low fatigue resistance;

- 0.51 to 0.8 moderate fatigue resistance

- Above 0.81 high fatigue resistance

However, it was empirically adapted in the table below because it considered better visualization, however, the main parameters were maintained.

Table 1. Fatigue resistance parameters, Adapted by the authors (2020)

\begin{tabular}{|l|l|}
\hline Categories: \\
\hline From 0 to 0.3 & Unsatisfactory \\
\hline From 0.31 to 0.5 & Weak \\
\hline From 0.51 to 0.8 & Average \\
\hline From 0.81 to 1,0 & Good \\
\hline Above 1,0 & Excellent \\
\hline
\end{tabular}

Form of collection of results of the Fighter-Specific Muscle Fatigue Index.

The formula was also maintained as follows (The result of the muscle fatigue test will be obtained by averaging the total number of repetitions of set 2 and set 3 divided by the total number of repetitions of set 1.)

\section{Musclefatigueindex}

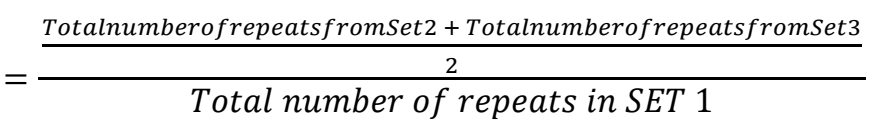

\footnotetext{
* Muscle fatigue

* Absolute result SET 1

* Absolute result SET 2
}

* Absolute result SET 3

* Borg scale.(6 a 20)

SURVEY PARTICIPANTS: The subjects of this research are all Jiu-jitsu practitioners and graduates in the black belt, male gender aged 27 to 50 years of national competitive level. All have more than 10 years of practice in jiu-jitsu.

SCENARIO: The test was carried out in a controlled environment in a space intended for martial arts practice on 50 $\mathrm{mm}$ tatami plates.

RISKS AND DIFFICULTY FOUND: All physical activity, especially when it comes to high-intensity interval training, will always bring risks regarding the high rates of heart rate, reaching the submaximal and maximum zones.Due to this aspect, all participants for safety had to be properly authorized to practice sports. We had to select as previously reported, practitioners with more than 10 years of practice in the modality, which consequently brought a lower risk margin with regard to injuries or deficiencies in the execution of movements.

The verification of parameters such as heart rate and Vo2 Max., are important follow-up factors that will certainly promote a detailed adjustment before, during and after training, observing, which is still considered that during, will act as a follow-up of the preparation process, and is directly linked to the result and safety of the proposed training system, but in this trial, due to the large number of participants, we chose to verify and evaluate the effort by subjective perception of exertion, the known and also efficient Borg scale. We worked with the Borg scale in the values of the table from 6 to 20 , where we had to divide groups of only 20 fighters per test battery so that one could have safety in the subjective evaluation of the effort. To reduce the margin of error in evaluations, we chose to always use the same evaluators.

\section{RESULTS}

Statistical treatment: For descriptive characteristics (SEP 1, SEP 2, SEP 3) and as dependent variables (Mov 1, Mov 2 and Mov 3), descriptive statistics (Number of repetitions (n), minimum values, maximum, amplitude, mean and standard deviation) are used. The correlation between the Mov values of the 3 scales was calculated and analysis was performed, followed to test the significance of the differences between SET and Mov in each category of mean, amplitude and standard deviation. Tables 2, 3 and 4 canbe concluded that the difference in age groups directly affects the total number of repetitions of the muscle fatigue test, and a higher standard deviation can be observed for older fighters.

Table 5 shows the results of the tests of the fatigue strength parameters. Regarding the above results, from 20 to 29 years, if we add the mean of the overall sum of each SET (rounds), we can observe that the number of repetitions was falling during the test, which already shows evidence of muscle fatigue. We can conclude with these top 3 tables that the difference in age group will directly influence the number of total repetitions of the muscle fatigue test and we can still observe a greater standard deviation for older fighters $48+44+43=135$ Total with a standard deviation of 2.5 for the first set (round), 0.8 for the second and 4.7 for the third. 
Age:

Weight

Height:

\begin{tabular}{|l|l|l|l|l|l|l|}
\hline & $\begin{array}{l}\text { Mov 1 (20') } \\
\text { Sprawl +Double leg }\end{array}$ & $\begin{array}{l}\text { Rest } \\
\text { (Fourthphoto) }\end{array}$ & $\begin{array}{l}\text { Mov 2 (20') } \\
\text { Kimura sit up }\end{array}$ & $\begin{array}{l}\text { Rest } \\
\text { (Fourthphoto) }\end{array}$ & $\begin{array}{l}\text { Mov 3 (20') } \\
\text { Knee on belly }\end{array}$ & $\begin{array}{l}\text { Rest between Sets (fourth photo } \\
\text { of each move) }\end{array}$ \\
\hline Set 1 & & secs.(20) & & secs.(20) & & secs.(20) \\
\hline Set 2 & & secs.(20) & & secs.(20) & & secs.(20) \\
\hline Set 3 & & secs.(20) & & secs.(20) & & secs.(20) \\
\hline
\end{tabular}

All exercises should be done as soon as possible while maintaining the technical quality of the movement

Final Result

Sig.

*Borgscale..............

Sig.

(6 to 20$)$

Note: this formula was used in each of the 100 fighters

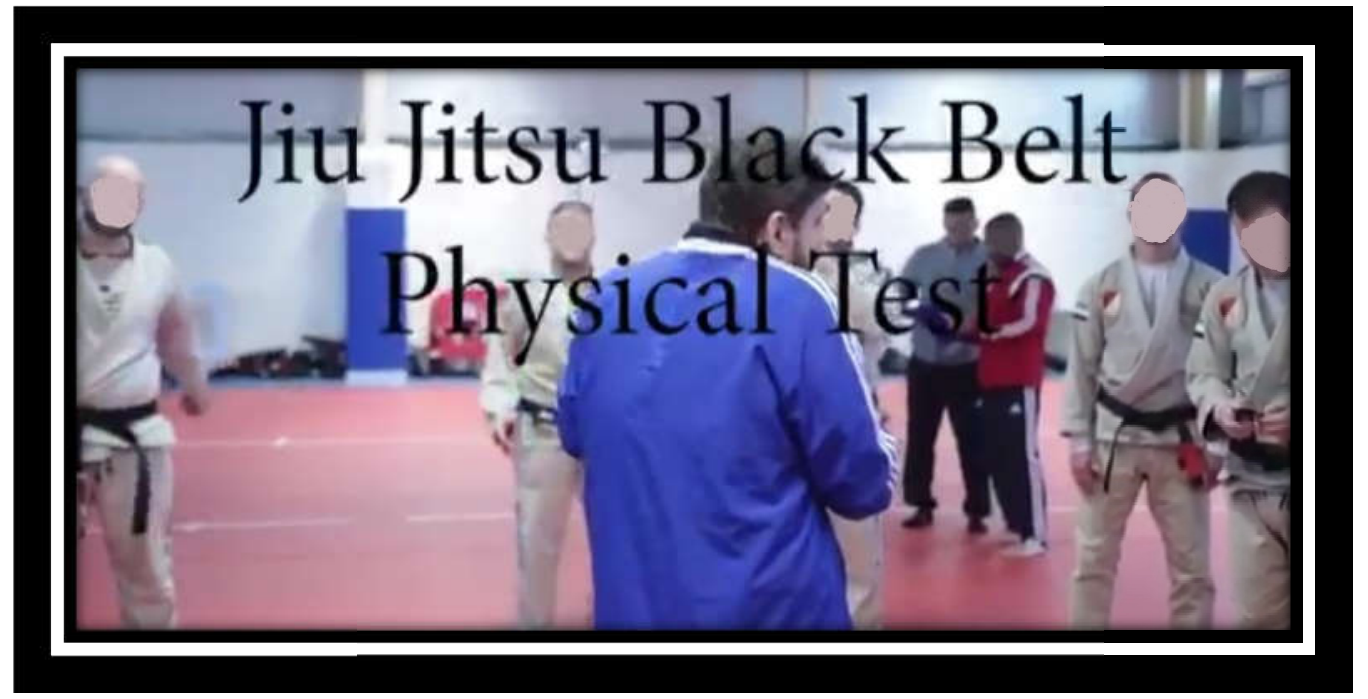

Figure 1. Guidelines for activity

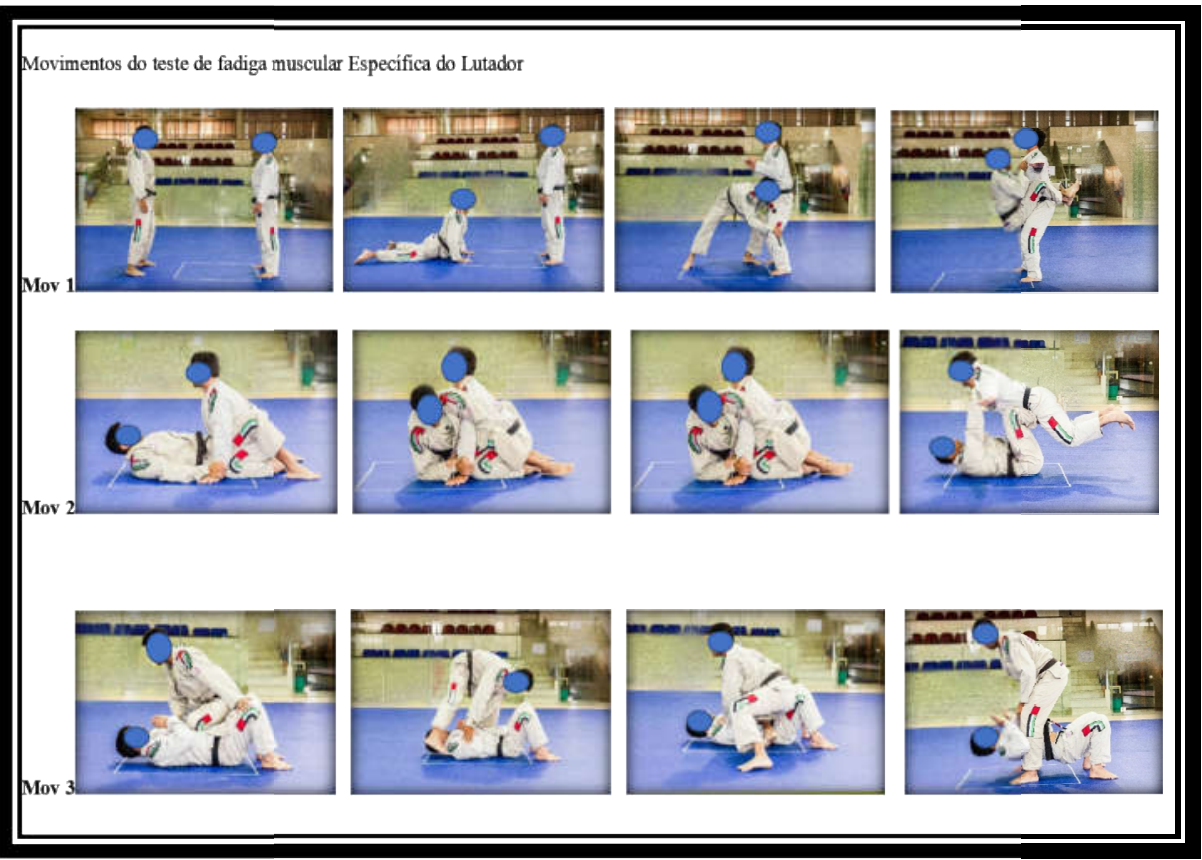

Figure 1. All the movements of the test 


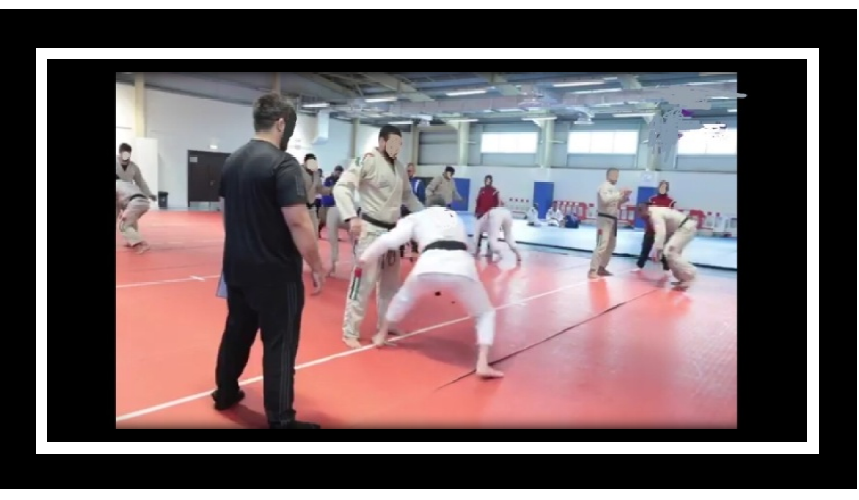

Figure 2. Start of the test

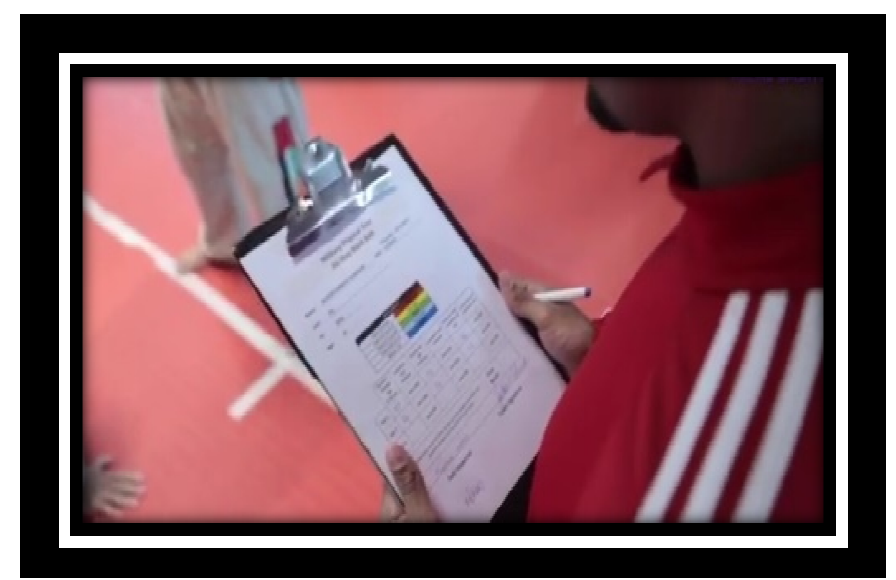

Figure 3. Data collection form

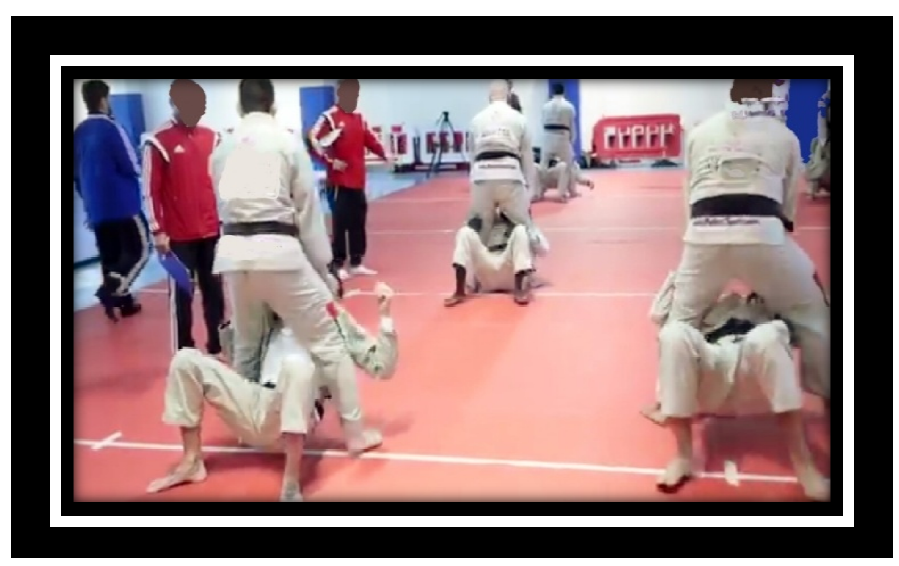

Figure 4. Movement Isometric Rest Interval 3

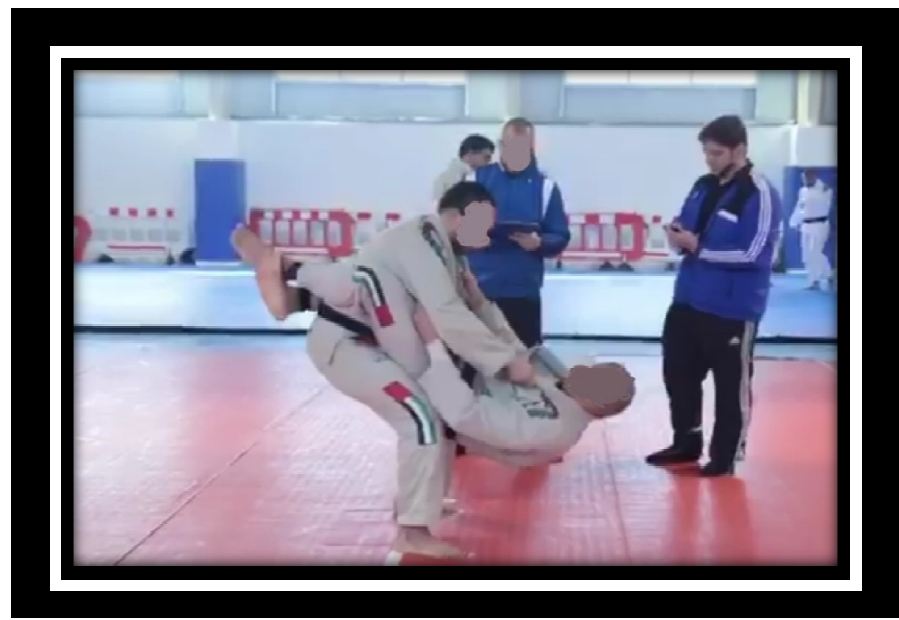

Figure 5. Isometric Movement Rest Interval 1
Regarding the above results, from 30 to 29 years, if we add the mean of the general sum of each SET (rounds), we can observe that the number of repetitions was also falling during the test and there is evidence again of muscle fatigue. However, the results are lower in Aplitudecadence (repetitions) compared to the previous $41+37+37=115$ with a standard deviation of 4.3 for the first Set (round), 3.9 for the second and 4.6 for the third. Regarding the above results, from 40 to 49 years, if we add the mean of the overall sum of each SET (rounds), we can observe that the number of repetitions was also falling during the test and there is evidence again of muscle fatigue. However, the results are lower in cadence (repetitions) compared to the previous $20+28+16=104$ with a standard deviation of 5.3 for the first Set (round), 5.6 for the second and 4.0 for the third.

Muscle fatigue index: The results found in the muscle fatigue index were not significant differences in relation to the age of the participants, this fact is due that this Index is obtained in relation to the athlete himself, that is, he competes against himself with each evaluation. Concerning this indicator, we can conclude that in this personalized result, the parameters that should be considered should be better with each evaluation, and not for another individual. However, with regard to the number of repetitions, we can observe and have a different view. An individual may have the same muscle fatigue index as the previous result, but with a higher movement rate and how the index is calculated in relation to sets, it is important that this aspect is considered in such a way that a fair and consistent assessment isobtained.

\section{Example:}

Athlete 1 obtained in the SEP 1, 10 repetitions, SEP 2, 10 repetitions and SET 310 repetitions with a total of 30 repetitions. If we calculate the index of muscle fatigue, we will find the result of 1 as index (excellent). Athlete 2 obtained in the SEP 1, 15 repetitions, SEP 2, 15 repetitions and SET 3, 15 repetitions with a total of 45 repetitions. If we calculate the index of muscle fatigue, we will also find the result of 1 as index (excellent). However, despite the same index of muscle fatigue, we will note that Athlete 2 was much higher in the number of absolute repetitions than Athlete 1. We can see in the table that the mean Borg scale was 16 and the mean muscle fatigue index was 0.89 . That's why this interesting tool allows us to analyze both the Index individually and also compare results between participants. The proposed activity is predominantly aerobic with high participation of lactic anaerobic and anaerobic metabolisms.

\section{ANALYSIS OF RESULTS}

Regarding the previous Table, some data can be analyzed so that we can draw some conclusions regarding this configuration of specific exercises with regard to highintensity interval training. The mean subjective perception of exertion that was found was 16 on the Borg scale. from 6 to 20. According to Del Vecchio (2019), these values would be sufficient to consider this type of activity as high-intensity interval training and with regard to this hypothesis, the response would have been very promising. With regard to the cadence of movements, where it will later be discussed and related to the Muscle Fatigue index, I chose to make a comparison of the 3 movements of the first SET in a global way, and compare it with the first SET by age group. 
Table 2. Statistical data Subjects 20 to 29 years old

\begin{tabular}{|l|l|l|l|l|l|l|l|l|l|l|l|l|l|l|l|}
\hline 20to 29 Years & \multicolumn{3}{l}{ SET 1 } & \multicolumn{3}{l|}{ SET 2 } & \multicolumn{1}{l|}{ SET 3 } \\
\hline STATISTICS & Age & Mov 1 & Mov2 & Mov3 & Total & Mov 1 & Mov 2 & Mov3 & Total & Mov 1 & Mov 2 & Mov 3 & TOTAL \\
\hline Number (n) & 3 & 3 & 3 & 3 & 3 & 3 & 3 & 3 & 3 & 3 & 3 & 3 & 3 \\
\hline Minimum & 27 & 11 & 17 & 16 & 45 & 9 & 18 & 14 & 43 & 9 & 16 & 14 & 40 \\
\hline Maximum & 29 & 12 & 21 & 18 & 51 & 12 & 20 & 15 & 45 & 12 & 20 & 18 & 50 \\
\hline Aplitude & 2 & 1 & 4 & 2 & 6 & 3 & 2 & 1 & 2 & 3 & 4 & 4 & 10 \\
\hline Average & 28 & 12 & 19 & 17 & 48 & 11 & 19 & 14 & 44 & 10 & 17 & 16 & 43 \\
\hline Standard deviation & 0,9 & 0,5 & 1,7 & 0,9 & 2,5 & 1,2 & 0,8 & 0,5 & 0,8 & 1,2 & 1,9 & 1,7 & 4,7 \\
\hline
\end{tabular}

Table 3. Statistical data. Subjects30 to 39 years old

\begin{tabular}{|c|c|c|c|c|c|c|c|c|c|c|c|c|c|}
\hline 30 to 39 Years & \multicolumn{3}{|c|}{ SET 1 } & \multicolumn{1}{c|}{ SET 2 } & \multicolumn{5}{c|}{ SET 3 } \\
\hline STATISTICS & Age & Mov 1 & Mov2 & Mov3 & Total & Mov 1 & Mov 2 & Mov3 & Total & Mov 1 & Mov 2 & Mov 3 & TOTAL \\
\hline Number (n) & 65 & 65 & 65 & 65 & 65 & 65 & 65 & 65 & 65 & 65 & 65 & 65 & 65 \\
\hline Minimum & 30 & 8 & 13 & 10 & 32 & 6 & 8 & 8 & 29 & 5 & 6 & 8 & 27 \\
\hline Maximum & 39 & 14 & 22 & 20 & 50 & 14 & 20 & 18 & 48 & 11 & 23 & 18 & 49 \\
\hline Aplitude & 9 & 6 & 9 & 10 & 18 & 8 & 12 & 10 & 19 & 6 & 17 & 10 & 22 \\
\hline Average & 35 & 11 & 16 & 14 & $\mathbf{4 1}$ & 10 & 15 & 13 & $\mathbf{3 7}$ & 9 & 15 & 13 & $\mathbf{3 7}$ \\
\hline Standarddeviation & 2,8 & 1,4 & 2,0 & 1,6 & 4,3 & 1,4 & 2,1 & 1,7 & 3,9 & 1,4 & 2,5 & 2,1 & 4,6 \\
\hline
\end{tabular}

Table 4. Statistical data. Subjects 40 to 49 years old

\begin{tabular}{|c|c|c|c|c|c|c|c|c|c|c|c|c|c|}
\hline \multicolumn{1}{|c|}{40 to 49 Years } & \multicolumn{4}{|c|}{ SET 2 } & \multicolumn{5}{c|}{ SET 3 } \\
\hline STATISTICS & Age & Mov 1 & Mov 2 & Mov 3 & Total & Mov 1 & Mov 2 & Mov 3 & Total & Mov 1 & Mov 2 & Mov 3 & TOTAL \\
\hline Number (n) & 31 & 31 & 31 & 31 & 31 & 31 & 31 & 31 & 31 & 31 & 31 & 31 & 31 \\
\hline Minimum & 40 & 6 & 12 & 9 & 28 & 6 & 3 & 8 & 19 & 5 & 9 & 9 & 26 \\
\hline Maximum & 48 & 14 & 23 & 18 & 48 & 11 & 19 & 18 & 47 & 11 & 16 & 17 & 42 \\
\hline Aplitude & 8 & 8 & 11 & 9 & 20 & 5 & 16 & 10 & 28 & 6 & 7 & 8 & 16 \\
\hline Average & 43 & 10 & 16 & 12 & $\mathbf{3 8}$ & 9 & 14 & 11 & $\mathbf{3 3}$ & 8 & 13 & 12 & $\mathbf{3 3}$ \\
\hline Standard deviation & 2,8 & 1,7 & 2,6 & 2,4 & 5,3 & 1,2 & 2,8 & 2,4 & 5,6 & 1,2 & 1,6 & 2,3 & 4,0 \\
\hline
\end{tabular}

\section{SET 1 (Predominant anaerobic cadence)}

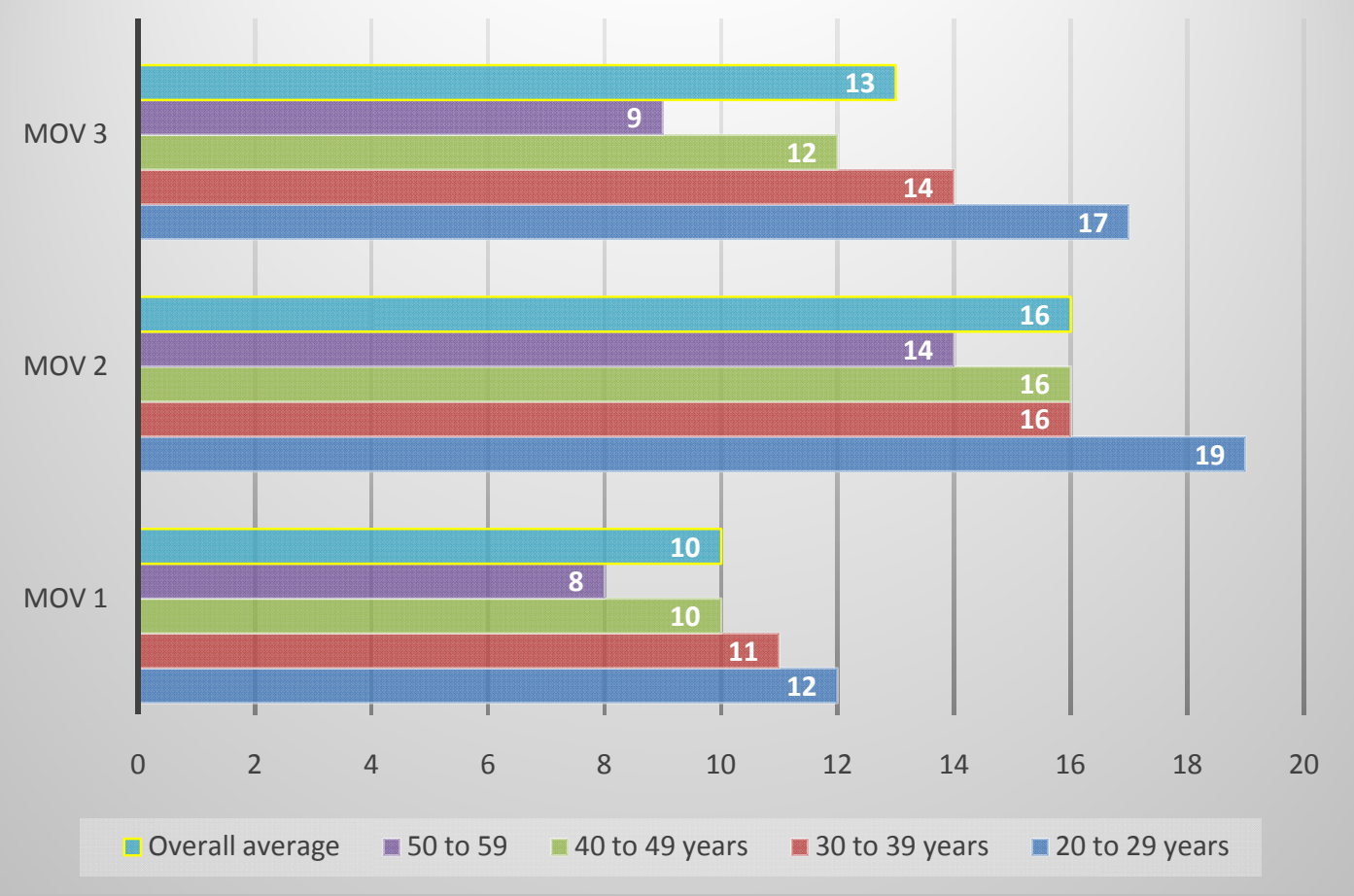

Figure 7. Graph of the number of repetitions (cadence) of the first SET. 
Table 5. Test results of muscle fatigue assessment

\begin{tabular}{|c|c|c|c|c|c|c|c|c|c|c|c|c|c|c|c|}
\hline $\mathrm{N}$ & ID & MOV 1 & MOV 2 & MOV 3 & SET 1. & MOV 1 & MOV 2 & MOV 3 & SET 2. & MOV 1 & MOV 2 & MOV 3 & SET 3. & INDEX & BORG \\
\hline 1 & 27 & 12 & 21 & 18 & 51 & 12 & 18 & 14 & 44 & 12 & 20 & 18 & 50 & 0,92 & 14 \\
\hline 2 & 29 & 11 & 20 & 16 & 47 & 9 & 19 & 15 & 43 & 9 & 16 & 15 & 40 & 0,88 & 15 \\
\hline 3 & 29 & 12 & 17 & 16 & 45 & 11 & 20 & 14 & 45 & 10 & 16 & 14 & 40 & 0,94 & 17 \\
\hline 4 & 30 & 9 & 14 & 14 & 37 & 8 & 12 & 12 & 32 & 7 & 10 & 11 & 28 & 0,81 & 17 \\
\hline 5 & 30 & 9 & 16 & 15 & 40 & 9 & 15 & 14 & 38 & 9 & 6 & 15 & 30 & 0,85 & 18 \\
\hline 6 & 30 & 12 & 18 & 13 & 43 & 11 & 17 & 12 & 40 & 11 & 16 & 14 & 41 & 0,94 & 15 \\
\hline 7 & 31 & 12 & 18 & 15 & 45 & 11 & 17 & 14 & 42 & 11 & 15 & 16 & 42 & 0,93 & 15 \\
\hline 8 & 31 & 12 & 16 & 12 & 40 & 9 & 15 & 9 & 33 & 8 & 4 & 9 & 31 & 0,8 & 17 \\
\hline 9 & 31 & 12 & 20 & 14 & 46 & 11 & 17 & 12 & 40 & 10 & 18 & 14 & 42 & 0,89 & 14 \\
\hline 10 & 31 & 13 & 17 & 15 & 45 & 12 & 17 & 15 & 44 & 11 & 17 & 13 & 41 & 0,94 & 16 \\
\hline 11 & 31 & 10 & 16 & 14 & 40 & 9 & 15 & 13 & 37 & 9 & 15 & 14 & 38 & 0,94 & 16 \\
\hline 12 & 31 & 11 & 15 & 14 & 40 & 10 & 15 & 13 & 38 & 10 & 15 & 14 & 39 & 0,96 & 16 \\
\hline 13 & 31 & 12 & 19 & 16 & 47 & 10 & 18 & 14 & 42 & 11 & 19 & 17 & 47 & 0,95 & 16 \\
\hline 14 & 32 & 12 & 16 & 16 & 44 & 10 & 15 & 16 & 41 & 9 & 15 & 17 & 41 & 0,93 & 16 \\
\hline 15 & 32 & 12 & 17 & 13 & 42 & 10 & 16 & 12 & 38 & 10 & 15 & 12 & 37 & 0,89 & 16 \\
\hline 16 & 32 & 14 & 20 & 16 & 50 & 14 & 16 & 14 & 44 & 11 & 15 & 14 & 40 & 0,84 & 16 \\
\hline 17 & 33 & 12 & 20 & 15 & 47 & 11 & 17 & 15 & 43 & 11 & 15 & 14 & 40 & 0,88 & 18 \\
\hline 18 & 33 & 14 & 18 & 12 & 44 & 9 & 18 & 13 & 40 & 9 & 14 & 13 & 36 & 0,86 & 17 \\
\hline 19 & 33 & 12 & 18 & 16 & 46 & 11 & 16 & 14 & 41 & 10 & 14 & 10 & 34 & 0,82 & 17 \\
\hline 20 & 34 & 12 & 22 & 15 & 49 & 10 & 18 & 13 & 41 & 10 & 19 & 12 & 41 & 0,84 & 17 \\
\hline 21 & 34 & 10 & 17 & 16 & 43 & 8 & 17 & 15 & 40 & 8 & 17 & 14 & 39 & 0,92 & 15 \\
\hline 22 & 34 & 12 & 18 & 13 & 43 & 10 & 18 & 12 & 40 & 10 & 17 & 10 & 37 & 0,9 & 15 \\
\hline 23 & 34 & 9 & 14 & 12 & 35 & 8 & 12 & 10 & 30 & 7 & 12 & 10 & 29 & 0.84 & 16 \\
\hline 24 & 34 & 10 & 17 & 14 & 41 & 9 & 16 & 12 & 37 & 9 & 14 & 13 & 36 & 0,89 & 16 \\
\hline 25 & 34 & 12 & 20 & 14 & 46 & 11 & 16 & 12 & 39 & 11 & 15 & 13 & 39 & 0,85 & 15 \\
\hline 26 & 34 & 10 & 20 & 20 & 50 & 10 & 20 & 18 & 48 & 11 & 20 & 18 & 49 & 0,97 & 14 \\
\hline 27 & 35 & 8 & 17 & 13 & 38 & 7 & 15 & 13 & 35 & 8 & 14 & 13 & 35 & 0,92 & 16 \\
\hline 28 & 35 & 13 & 17 & 14 & 44 & 10 & 18 & 11 & 39 & 8 & 17 & 16 & 41 & 0,91 & 16 \\
\hline 29 & 35 & 10 & 14 & 12 & 36 & 9 & 13 & 8 & 30 & 9 & 12 & 9 & 30 & 0,83 & 16 \\
\hline 30 & 35 & 12 & 17 & 14 & 43 & 9 & 17 & 12 & 38 & 10 & 15 & 12 & 37 & 0,87 & 16 \\
\hline 31 & 35 & 12 & 19 & 15 & 46 & 11 & 15 & 13 & 39 & 11 & 15 & 14 & 40 & 0,86 & 15 \\
\hline 32 & 35 & 12 & 14 & 13 & 39 & 12 & 14 & 12 & 38 & 10 & 15 & 12 & 37 & 0,96 & 16 \\
\hline 33 & 35 & 11 & 17 & 14 & 42 & 12 & 15 & 13 & 40 & 11 & 17 & 13 & 41 & 0,96 & 15 \\
\hline 34 & 36 & 11 & 18 & 14 & 43 & 11 & 16 & 13 & 40 & 11 & 14 & 13 & 38 & 0,91 & 16 \\
\hline 35 & 36 & 10 & 16 & 14 & 40 & 9 & 13 & 14 & 36 & 10 & 13 & 15 & 38 & 0,93 & 15 \\
\hline 36 & 36 & 10 & 13 & 13 & 36 & 11 & 10 & 12 & 33 & 10 & 10 & 12 & 32 & 0,9 & 14 \\
\hline 37 & 36 & 12 & 15 & 13 & 40 & 12 & 15 & 12 & 39 & 11 & 14 & 11 & 36 & 0,94 & 16 \\
\hline 38 & 36 & 10 & 15 & 12 & 37 & 10 & 14 & 12 & 36 & 8 & 15 & 11 & 34 & 0,95 & 15 \\
\hline 39 & 36 & 11 & 18 & 14 & 43 & 10 & 18 & 12 & 40 & 9 & 19 & 14 & 42 & 0,95 & 17 \\
\hline 40 & 37 & 12 & 18 & 15 & 45 & 11 & 16 & 15 & 42 & 10 & 15 & 15 & 40 & 0,91 & 17 \\
\hline 41 & 37 & 9 & 16 & 13 & 38 & 9 & 13 & 13 & 35 & 8 & 13 & 12 & 33 & 0,89 & 15 \\
\hline 42 & 37 & 9 & 14 & 12 & 35 & 9 & 13 & 11 & 33 & 8 & 13 & 12 & 33 & 0,94 & 15 \\
\hline 43 & 37 & 11 & 16 & 16 & 43 & 10 & 16 & 15 & 41 & 9 & 15 & 16 & 40 & 0,94 & 15 \\
\hline 44 & 37 & 9 & 13 & 12 & 34 & 8 & 14 & 11 & 33 & 8 & 13 & 11 & 32 & 0,96 & 17 \\
\hline 45 & 37 & 9 & 15 & 13 & 37 & 8 & 15 & 13 & 36 & 7 & 15 & 13 & 35 & 0,96 & 17 \\
\hline 46 & 38 & 10 & 17 & 14 & 41 & 10 & 17 & 14 & 41 & 8 & 15 & 12 & 35 & 0,93 & 15 \\
\hline 47 & 38 & 11 & 16 & 14 & 41 & 9 & 14 & 12 & 35 & 9 & 13 & 12 & 34 & 0,84 & 17 \\
\hline 48 & 38 & 11 & 17 & 14 & 42 & 10 & 16 & 13 & 39 & 10 & 16 & 13 & 39 & 0,93 & 14 \\
\hline 49 & 38 & 11 & 15 & 15 & 41 & 8 & 14 & 14 & 36 & 8 & 13 & 13 & 34 & 0,85 & 17 \\
\hline 50 & 38 & 10 & 15 & 13 & 38 & 10 & 14 & 12 & 36 & 8 & 14 & 12 & 34 & 0,92 & 15 \\
\hline 51 & 38 & 8 & 13 & 11 & 32 & 7 & 12 & 10 & 29 & 5 & 13 & 11 & 29 & 0,91 & 15 \\
\hline 52 & 38 & 8 & 13 & 11 & 32 & 7 & 12 & 10 & 29 & 7 & 12 & 10 & 29 & 0,91 & 14 \\
\hline 53 & 38 & 12 & 18 & 12 & 42 & 10 & 17 & 11 & 38 & 10 & 15 & 13 & 38 & 0,9 & 15 \\
\hline 54 & 38 & 10 & 16 & 12 & 38 & 9 & 14 & 10 & 33 & 8 & 11 & 8 & 27 & 0,79 & 18 \\
\hline 55 & 38 & 11 & 20 & 12 & 43 & 11 & 17 & 11 & 39 & 9 & 15 & 15 & 39 & 0,91 & 14 \\
\hline 56 & 38 & 9 & 14 & 11 & 34 & 9 & 14 & 10 & 33 & 8 & 14 & 10 & 32 & 0,96 & 15 \\
\hline 57 & 38 & 8 & 13 & 12 & 33 & 8 & 14 & 10 & 32 & 8 & 12 & 10 & 30 & 0,94 & 16 \\
\hline 58 & 38 & 10 & 17 & 14 & 41 & 9 & 17 & 14 & 40 & 9 & 15 & 13 & 37 & 0,94 & 16 \\
\hline 59 & 38 & 11 & 15 & 13 & 39 & 10 & 13 & 13 & 36 & 10 & 15 & 14 & 39 & 0,96 & 14 \\
\hline 60 & 38 & 11 & 15 & 13 & 39 & 9 & 14 & 14 & 37 & 9 & 13 & 14 & 36 & 0,94 & 15 \\
\hline 61 & 38 & 10 & 16 & 12 & 38 & 9 & 15 & 13 & 37 & 8 & 16 & 12 & 36 & 0,96 & 16 \\
\hline 62 & 39 & 10 & 16 & 11 & 37 & 6 & 15 & 10 & 31 & 6 & 14 & 9 & 29 & 0,81 & 19 \\
\hline 63 & 39 & 12 & 18 & 14 & 44 & 10 & 8 & 14 & 32 & 11 & 23 & 14 & 48 & 0,91 & 15 \\
\hline 64 & 39 & 13 & 16 & 14 & 43 & 11 & 17 & 13 & 41 & 11 & 15 & 11 & 37 & 0,91 & 15 \\
\hline 65 & 39 & 11 & 15 & 13 & 39 & 9 & 14 & 14 & 37 & 9 & 13 & 14 & 36 & 0,94 & 15 \\
\hline 66 & 39 & 9 & 15 & 13 & 37 & 8 & 16 & 12 & 36 & 8 & 15 & 11 & 34 & 0,95 & 17 \\
\hline 67 & 39 & 11 & 16 & 14 & 41 & 9 & 16 & 14 & 39 & 10 & 16 & 13 & 39 & 0,95 & 15 \\
\hline 68 & 39 & 10 & 17 & 13 & 40 & 8 & 15 & 13 & 36 & 9 & 15 & 14 & 38 & 0,93 & 15 \\
\hline 69 & 40 & 14 & 17 & 17 & 48 & 10 & 19 & 18 & 47 & 11 & 12 & 17 & 40 & 0,91 & 16 \\
\hline 70 & 40 & 11 & 17 & 18 & 46 & 10 & 17 & 17 & 44 & 10 & 16 & 16 & 42 & 0,93 & 16 \\
\hline
\end{tabular}




\begin{tabular}{|c|c|c|c|c|c|c|c|c|c|c|c|c|c|c|c|}
\hline 69 & 40 & 14 & 17 & 17 & 48 & 10 & 19 & 18 & 47 & 11 & 12 & 17 & 40 & 0,91 & 16 \\
\hline 70 & 40 & 11 & 17 & 18 & 46 & 10 & 17 & 17 & 44 & 10 & 16 & 16 & 42 & 0,93 & 16 \\
\hline 71 & 40 & 9 & 23 & 12 & 44 & 6 & 16 & 11 & 33 & 7 & 16 & 11 & 34 & 0,76 & 19 \\
\hline 72 & 40 & 10 & 17 & 13 & 40 & 8 & 14 & 11 & 33 & 8 & 13 & 12 & 33 & 0,83 & 17 \\
\hline 73 & 40 & 10 & 19 & 16 & 45 & 8 & 16 & 14 & 38 & 8 & 15 & 16 & 39 & 0,86 & 16 \\
\hline 74 & 40 & 11 & 18 & 12 & 41 & 9 & 17 & 11 & 37 & 9 & 15 & 12 & 36 & 0,89 & 17 \\
\hline 75 & 40 & 7 & 15 & 11 & 33 & 8 & 13 & 10 & 31 & 7 & 13 & 10 & 30 & 0,92 & 14 \\
\hline 76 & 40 & 10 & 17 & 13 & 40 & 9 & 14 & 11 & 34 & 8 & 13 & 10 & 31 & 0,81 & 15 \\
\hline 77 & 40 & 10 & 16 & 14 & 40 & 10 & 14 & 13 & 37 & 9 & 14 & 13 & 36 & 0,91 & 15 \\
\hline 78 & 40 & 10 & 13 & 13 & 36 & 9 & 14 & 12 & 35 & 9 & 14 & 11 & 34 & 0,96 & 15 \\
\hline 79 & 40 & 9 & 15 & 10 & 34 & 8 & 13 & 11 & 32 & 7 & 13 & 12 & 32 & 0,94 & 15 \\
\hline 80 & 41 & 12 & 21 & 11 & 44 & 10 & 14 & 9 & 33 & 9 & 14 & 9 & 32 & 0,74 & 19 \\
\hline 81 & 41 & 10 & 13 & 16 & 39 & 9 & 12 & 11 & 32 & 8 & 12 & 11 & 31 & 0,81 & 16 \\
\hline 82 & 41 & 12 & 17 & 14 & 43 & 11 & 15 & 11 & 37 & 9 & 14 & 11 & 34 & 0,83 & 17 \\
\hline 83 & 41 & 9 & 14 & 10 & 33 & 8 & 3 & 8 & 19 & 7 & 12 & 10 & 29 & 0,73 & 19 \\
\hline 84 & 41 & 8 & 12 & 11 & 31 & 7 & 10 & 9 & 26 & 7 & 10 & 11 & 28 & 0,87 & 15 \\
\hline 85 & 41 & 13 & 17 & 17 & 47 & 10 & 17 & 16 & 43 & 9 & 15 & 17 & 41 & 0,89 & 16 \\
\hline 86 & 42 & 10 & 16 & 14 & 40 & 9 & 15 & 13 & 37 & 8 & 15 & 11 & 34 & 0,89 & 17 \\
\hline 87 & 43 & 9 & 16 & 11 & 36 & 9 & 13 & 11 & 33 & 9 & 14 & 11 & 34 & 0,93 & 14 \\
\hline 88 & 43 & 9 & 14 & 10 & 33 & 8 & 12 & 8 & 28 & 8 & 11 & 10 & 29 & 0,86 & 15 \\
\hline 89 & 43 & 10 & 14 & 11 & 35 & 8 & 13 & 11 & 32 & 8 & 14 & 12 & 34 & 0,94 & 14 \\
\hline 90 & 45 & 11 & 15 & 12 & 38 & 9 & 15 & 12 & 36 & 10 & 13 & 12 & 35 & 0,93 & 16 \\
\hline 91 & 45 & 8 & 13 & 10 & 31 & 8 & 12 & 10 & 30 & 7 & 11 & 9 & 27 & 0,92 & 15 \\
\hline 92 & 45 & 10 & 14 & 11 & 35 & 10 & 14 & 10 & 34 & 9 & 13 & 10 & 32 & 0,94 & 16 \\
\hline 93 & 45 & 10 & 15 & 13 & 38 & 9 & 15 & 14 & 38 & 10 & 14 & 12 & 36 & 0,97 & 15 \\
\hline 94 & 46 & 9 & 14 & 13 & 36 & 9 & 14 & 12 & 35 & 8 & 13 & 11 & 32 & 0,93 & 15 \\
\hline 95 & 47 & 8 & 19 & 10 & 37 & 9 & 13 & 9 & 31 & 8 & 13 & 9 & 30 & 0,82 & 17 \\
\hline 96 & 47 & 9 & 12 & 10 & 31 & 8 & 10 & 9 & 27 & 8 & 9 & 10 & 27 & 0,87 & 16 \\
\hline 97 & 47 & 7 & 13 & 9 & 29 & 6 & 11 & 9 & 26 & 7 & 12 & 10 & 29 & 0,95 & 16 \\
\hline 98 & 48 & 6 & 12 & 10 & 28 & 6 & 11 & 9 & 26 & 5 & 12 & 9 & 26 & 0,93 & 14 \\
\hline 99 & 48 & 10 & 17 & 13 & 40 & 8 & 14 & 12 & 34 & 8 & 13 & 15 & 36 & 0,88 & 16 \\
\hline 100 & 50 & 8 & 14 & 9 & 31 & 7 & 13 & 10 & 30 & 6 & 9 & 9 & 24 & 0,87 & 17 \\
\hline
\end{tabular}

\section{0 to 29 years old 30 to 39 years old}

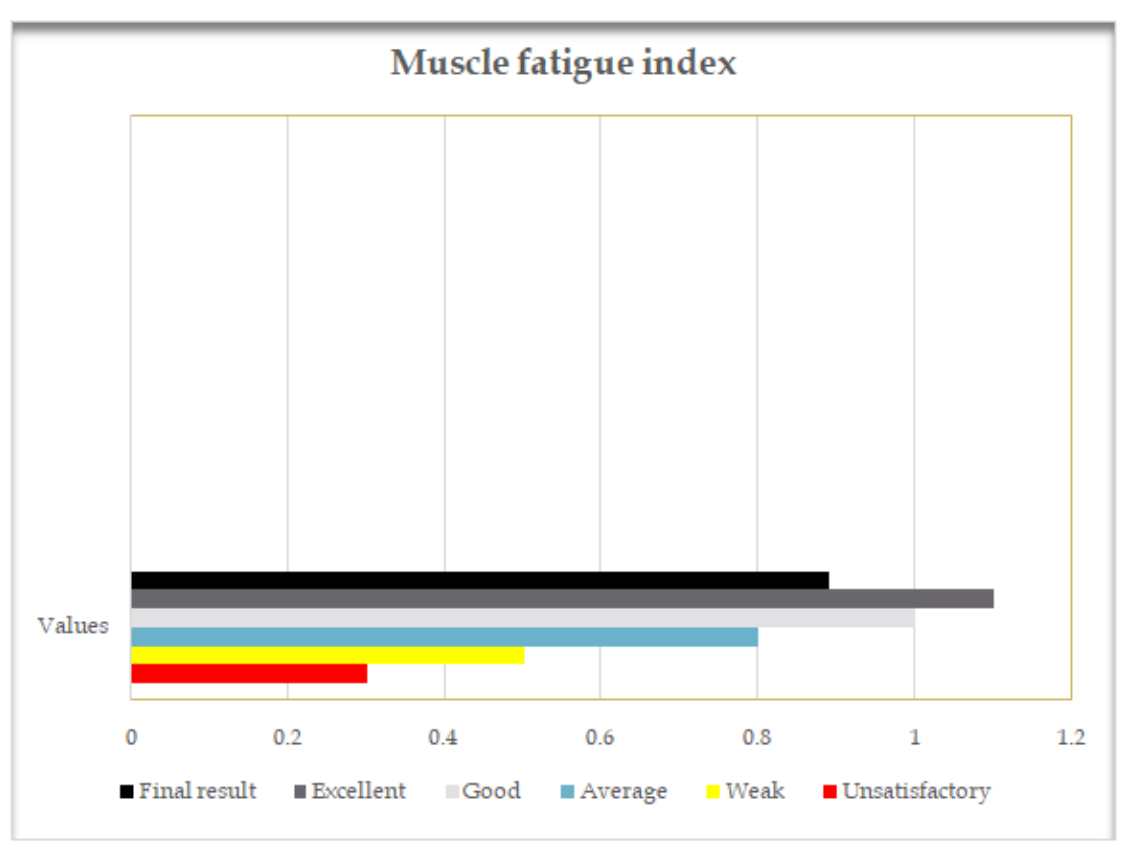

Figure 8. Graph of the average muscle fatigue index

The choice of this cadence of the first movement, which is between 0 and 20 seconds, means work with energy consumption of $82 \%$ anaerobic and $18 \%$ aerobic that is of paramount importance for the modality in question because it has a determining character within a sport of grab combat as is jiu-jitsu. We should not confuse determinant with predominant, because as shown in the Table of energy expenditures verses, working time, what will prevail after 75 seconds or 1 minute and 15 seconds is aerobic consumption with $51 \%$.
In the measurement of our second movement, it is still with higher anaerobic energy expenditure with $55 \%$, it is a very relevant check with regard to the determining characteristics within a fight. Only then, at the end of the third movement that we will have an inversion with $40 \%$ anaerobic, which is still a high value, from this point the predominance of energy expenditure will be aerobic, but with the high demand for glycolytic metabolism. 
Anaerobic abilities can determine the outcome of combat, as the fighter needs to develop them, thereby increasing their ability, for example, to exchange footprints, explosions of movements that can lead to a comfortable position to achieve victory falls applications and submissions at crucial moments within a fight. In the chart below you can see the average cadence (number of repetitions) in SET 1 of the overall result, compared with the mean by age group. We can observe that when comparing all the results together, we obtained a general mean of the movement cadence, we found a significant difference when compared by age group mainly in MOV 1 (Sprawl + Double leg). Next, we can see a large difference still, but in the category 20 to 29 years in relation to the general average, however from 30 to 39 and 40 to 49 years there was no significant difference, while in the age group 50 to 59 there is a significant difference in the movement cadence in MOV 2 (Kimura sit up). Finally, the cadence difference is rising again in the first two age groups from 20 to 29 years and 30 to 39 years, but this time it was balanced with the category of 40 to 49 years, however once again the category 50 to 59 signaled lower cadence in MOV 3 (Knee on belly). We can observe that in relation to the general observation of the cadence of the whole SET 1, the age group can influence the number of total repetitions, which in turn is directly linked to the speed of movement execution, suggesting that younger athletes have higher power for exercises that have predominantly anaerobic energy expenditure.

Regarding the proposed muscular fatigue test, at the end of all SETs, a general average of 0.89 specific muscle fatigue indexwas observed for jiu-jitsu, where this value in the Table represents one good resistance to muscle fatigue, this fact may be correlated with all subjects tested having more than 10 years of practice and being experienced black belts and who are already familiar with all movements, however, high values were found in the subjective perception of exertion scale, a general average of 16 , evidence that at the end of the test, the efforts were in the proportion of submaximalimalto maximum, and had anaerobic predominance, because only the first SET had anaerobic predominance.

\section{Conclusion}

According to all the results obtained we can verify that it is an evaluation tool that complies with the requirements of an activity characterized as circuit training, with active recovery, so it has higher caloric expenditure in the training section, as well as oxygen consumption and even a higher average heart rate in training because the subjective perception of mean effort among the subjects tested was 16 on the Borg scale.Studies indicate that this configuration promotes a higher lactate production and even more when recovery periods are short, close to 30 seconds that was the case of physical activity in question.Regarding the use of this tool as an assessment of specific muscle fatigue, all subjects had a general decrease in the cadence of movements, which is already observed a Fatigue and muscle wear during the test, despite the good performance of all participants, the tool suggests that the degree of experience and level of trainability can directly influence the results.We can also observe that older athletes have a considerably lower cadence than younger athletes. This difference is not so marked when we observe the values of the Fatigue index, this is explained because the index is a relationship of the athlete with himself and not in comparison with the others.
What will differentiate one athlete from another and can be used as a reference is directly linked to the cadence of movement'snumber of repetitions. We can conclude then that, in addition to being able to evaluate the muscle fatigue index, we can also evaluate the number of repetitions per SET, as a measurement parameter in the increase in the speed of movement execution for a given time, as well as aspects related to the technical quality of movements, through the descriptive observatory method.Indirectly, we can evaluate the number of repetitions per set, allowing evaluating the speed and technical quality of the movements with an excellent connection between the test and the modality.

(Technique, Endurance, Flexibility, Speed, Strength).

\section{Nines important factors that highlight the relevance of the work}

- Numerically points of results;

- Quantifies and reports performance;

- Rate participants;

- Analyzes strengths and weaknesses;

- Gets numbers to draw a plan;

- Has total connection with the activity;

- Checks progress;

- Motivates participants through reports;

- It is based on scientific evidence.

It is concluded that this proposal meets the initial objectives and will, in addition, this concept can be used for any type of physical activity and various types of sports gestures, thus being an excellent tool for teachers and technicians, and can also be used as part of a physical preparation structure for combat modalities in several specific phases of training.

\section{BIBLIOGRAPHIC REFERENCES}

Artigos e informações atualizadas sobre Jiu-Jitsu, Submisson Wrestling, Grappling e MMA. Disponíveis em: $<$ www.portaldovt.com.br> e Jornal do Vale-Tudo. Rio de Janeiro: Editora SEGMIDIA

Artigos e informações atualizadas sobre Jiu-Jitsu, Submisson Wrestling, Grappling e MMA. Dispo- níveis em: $<$ www.tatame.com.br> e Revista Tatame. Rio de Janeiro: Editora Nova Tríade do Brasil Ltda.

Artigos e informações atualizadas sobre Jiu-Jítsu, Submisson Wrestling, Grappling e MMA. Disponíveis em: $<$ www.graciemag.com> e Revista Gracie Magazine. Rio de Janeiro: Editora Gracie Ltda.

Baffa, A. \& Barros Júnior, E. 2002. As principais lesões no jiu-jitsu. Revista Fisioterapia Brasil, v.3, n.6, p.377-381.

Bedolla, A. 2002. Definicióndel campo táctico del taekwondo. Disponivel em: <www.efdeportes.com>. Acesso em: jun. 2019.

Bedolla, A. 2003. Estratégia Táctica y Técnica: definiciones, características y ejemplos de los controvertidos términos. Disponível em: <www efdeportes.com>. Acesso em: jun. 2019.

Bianchi, S.; et al. 2005. Caracterização Morfofuncional de atletas praticantes do Brazilian Jiu-Jitsu. In XIII Congresso Interno de Iniciação Cientifica da Unicamp, Campinas-SP. 
Bolelli, D. 2003. Mixed Martial Arts: A technical analysis of the Ultimate Fighting Championship in its formative years. Journal of Asian Martial Arts, v 12, n.3, p.41-51.

Bompa, T. 2004. Treinamento de Poténcia para o esporte. São Paulo: Phorte Editora

Borg, G. 2000. Escalas de Borg para dor e o esforço percebido. Barueri: Manole.

Bouhlel, E.; Jouini, A.; Gmada, N.; Nefzi, A.; Ben Abdallah, K. \&Tabka, Z. 2006. Heart rate and blood lactate responses during Taekwondo training and competition. Science and Sports, v.21, n.5, p.285 290.

Cabrera, R. 2006. La acción táctica em lascompeticiones de combate. Deporte: Karate-do. Disponível em: $<$ www.efdeportes.com>. Acesso em: jun. 2019.

Calmet, M. \&Ahmaidi, S. 2004. Survey of advantages obtained by judoka in competition by level of practice. Perceptual and Motor Skills, v.99, n.1, p.284-90.

Carnaval, P. E. 2002. Medidas e Avaliação em Ciência do Esporte. $5^{\text {a }}$ ed. Rio de Janeiro: Sprint.

Cooper, K. H. 1972. Capacidade aeróbia. Rio de Janeiro: Fórum.

Del Vecchio, E.; Bianchi, S.; Hirata, S. \&Chacon- Mikahil, M. 2007. Análise morfo-funcional de praticantes de brazilian jiu-jitsu e estudo da temporalidade e da quantificação das ações motoras na modalidade. Movimento \& Percepção, v.7, n.10, p.263-281

Dintiman, G.; Ward, B. \&Tellez, T. 1999. Velocidade nos Esportes. 2.a edição. Barueri: Editora Manole.

Drigo, J: Amorim, A.; Martins, C. \& Molina, R. 1996. Demanda metabólica em lutas de projeção e de solo no judô: estudo pelo lactato sanguíneo. Motriz, v.2, n.2, p.8086.

Edwards, S. 1994. O livro do monitor de frequência cardíaca. 1.a edição. Finlândia: Polar Electro.

Farinatti, P. \& Monteiro, W. 2000. Fisiologia e Avaliação Funcional. 4. edição. Rio de Janeiro: Editora Sprint.

Farinatti, P. 1992. Fisiologia e avaliação funcional. São Paulo: Sprint.

Fernandes Filho, J. 1999. A Prática da Avaliação Física. Rio de Janeiro: Editora Shape.

Fernandes Filho, J. 2004. Treinamento Desportivo: Descoberta de Talentos. Rio de Janeiro: Editora Shape.

Ferreira, A. 2004. Perfil dermatoglifico, somatotípico e das qualidades fisicas de atletas brasileiros de corrida de orientação de alto rendimento. Dissertação de mestrado em ciència da motricidade humana apresentada à Universidade Castelo Branco, Rio de Janeiro.

FILA Word Grappling Committee. 2008. RegrasInternacionais de Grappling. Tradução: Francis FrapolliAbramson; Interpretação: Sylvio Behring. Disponível em: <http:/www.cbla.com.br/ lutas Grappling.htm>. Acessoem: jun. 2019

Fleck, S. 1983. Body composition of elite American athletes. The American Journal of Sports Medici- 39 ne, v.1l, n.6, p.398-403.

Fonseca, R. 2006. Propuesta metodológica para incluir enel programa de preparacióndeldeportista modelos técnicotácticos del taekwondo em los objetivos pedagógicos deportivos. Disponível em: <www.efdeportes.com>. Acesso em: jun. 2019.

Franchini, E. \& Del Vecchio, F. 2008. Preparação Física para atletas de Judô. São Paulo: Phorte Editora.

Franchini, E. \&Sterkowicz, S. 2003. Tática e técnica no judô de alto nível 1995-2001: considerações sobre as categorias de peso e os gêneros. Revista Mackenzie de Educação Física e Esporte, v.2, n.2, p.125-38.

Franchini, E. 2001. Judó: Desempenho Competitivo. 1.de edição. Barueri: Editora Manole.

Franchini, E. 2001. Judò: Desempenho Competitivo. Barueri: Editora Manole.

Franchini, E.; Nunes, A.; Moraes, J. \& Del Vecchio, F. 2007. Physical fitness and anthropometrical pro- file of the Brazilian male judo team. Journal of Physiological Anthropology, v.26, n.2, p.59-67.

Franchini, E.; Sterkowicz, S.; Meira, C.; Gomes F. \&Tani, G. 2008. Technical variation in a sample of high level judo players. Perceptual and Motor Skills, v.106, n.3, p.859-69.

Franchini, E.; Takito, M. \& Pereira, J. 2003. Freqüência cardíaca e força de preensão manual durante a luta de jiujitsu. Disponível em: <www.efdeportes.com>. Acesso em: jun. 2019.

Gentil, P. 2004. Lactato, acidose e Fatigue. Disponível em: $<$ www.gease.com.br>. Acessoem: jun. 2019.

Ghosh, A.; Goswami, A. \& Ahuja, A. 1995. Heart rate \& blood lactate response in amateur competitive boxing. Indian Journal of Medicine Research, v24 n. 102, p.179183.

Gomiero, F. 2008. Ciclo PDCA: Uma ferramenta de qualidade indispensável no mundo dos negócios. Disponível em: $<$ www.janelanaweb.com/ digitais/gomiero23.html $>$. Acesso em: jun. 2019.

Huang et al. 2006. On the mechanism of the effects of sportswear colour on contest outcome. Medicine \& Science in Sports \& Exercise, v.38, n.5, p.S227.

Imamura, R.; Hreljac, A.; Escamilla, R. \& Edwards, W. 2006. A three dimensional analysis of the center of mass for three different judo throwing techniques. Journal of Sports Science and Medicine, v.5, p.122-131.

Indianapolis. 2000. American College of Sports Medicine. Manual do ACSM para Teste de Esforço e Prescrição de Exercicio. 5.a edição. Rio de Janeiro: Editora Revinter.

Janjaque, M. 2007. El Judô: controldelrendimiento táctico. Disponível em: <www.judobrasil com.br>. Acesso em: jun. 2019.

Jesus, C.; Costa, E.; Ferreira, C.; Taccolini, F.; Ferreira, A.; Dias, O. \& Albergaria, M. 2005. Correlação entre o volume de perna corrigida e braço corrigido de praticantes de jiujitsu. Revista cientifica anuário do LAFIEX, a.II, n.2.

Kraemer, W. \&Häkkinen, K. 2004. Treinamento de Força para o Esporte. Porto Alegre: Editora Artmed.

Lima, E.; Tortoza, C.; Rosa, L. \& Lopes-Martins, R. 2004. Estudo da correlação entre a velocidade de reação motora e o lactato sanguíneo, em diferentes tempos de luta no Judó. Revista Brasileira de Medicina do Esporte, v.10, n.5, p.339-343.

Mancini, A.; Machado, H.; Keller, B. \& Santos, S. 2008. Associação entre o perfil antropométrico e o desempenho de atletas de luta olímpica. Disponível em: $<$ www.efdeportes.com>. Acesso em: jun. 2019.

Mathias, A.; Ferreira, C.; Siqueira, T. \& Souza, W. 2003. Ácido lático: Fato ou Ficção? Revista Digital Vida e Saúde, v.2, n.5, p. 10.

Matsudo, V. 2000. Testes em Ciências do Esporte CD ROM. São Paulo: CELAFISCS.

Matsumoto, D.; Konno, J.; Hata, S. \&Takeuchi, M. 2007. Blue judogis may bias competition outcomes. In Annals of the 5th International Judo Federation World Research Symposium, Rio de Janeiro, Brazil. 
Medeiros, H.; Leites, T.; Silva, I. \& Almeida, A. 2006. O perfil Dermatoglifico e Somatotípico de atletas de Vale-Tudo da equipe Nova União do Rio de Janeiro. In. XXIX Simpósio Internacional de ciência do Esporte, São Paulo.

Medeiros, H.; Silva, I. \& Dantas, P. 2005. Perfil Dermatoglífico e das qualidades físicas básicas de atletas de Jiu-Jitsu. In: $9^{\circ}$ Simpósio Internacional de atividades fisicas do Rio de Janeiro.

Medeiros, H.; Silva, I. \& Gomes, A. 2004. A composição corporal e a somatotipologia no alto rendimento do JiuJitsu brasileiro. In: Coleção pesquisa em educação fisica, n.4. São Paulo: Editora Fontoura.

Medeiros, H.; Silva, I.; Amorim, L. \& Dantas, P. 2005. Análise da correlação entre um dos indicativos de pré-disposição genética à coordenação e o teste de Burpee em atletas de Jiu-Jitsu. In: 9 Simpósio Internacional de atividades físicas do Rio de Janeiro.

Melo, R. 2001. Apostila de Treinamento Desportivo. Rio de Janeiro.

Milanovic, D.; Jukic, I.; Šimek, S. \&Bok, D. 2006. Diagnosing sports preparedness of ultimate fighters. In: 1 Word Scientific Congress of Combat Sports and Martial Arts, Poland.

Molinari, B. 2000. Avaliação Médica e Fisica. 1.a edição. São Paulo: Editora Roca.

Mori, S.; Ohtani, Y. \&Imanaka, K. 2002. Reaction times and anticipatory skills of karate athletes. Human Movement Science, v.21, n.2, p.213-30.

National Geografic Channel. 2008. Fight Science reveals the science behind mixed martial arts, special operations, and self-defense. Disponível em: $<$ http://channel.nationalgeographic.com/series/fightscience/all/Overview>. Acesso em: jun. 2019.

Paiva, L. \& Paiva, L. 2005. Anotações das Avaliações Físicas realizadas com 6 atletas de elite de Jiu-Jitsu, sendo 3 desses atletas participantes de eventos nacionais $e$ internacionais de Vale-Tudo da- dos não publicados. Amazonas: Laboratório de Avaliação Física Desportiva e Estética Lafide.

Paiva, Leandro2004. Apostila do Curso de Treinamento Desportivo aplicado ao Vale-Tudo, Submission e Jiu-Jitsu. Amazonas.

Paiva, Leandro2015. Olhar Clínico nas Lutas, Artes Marciais e Modalidades de Combate/Leandro Paiva. -1. ed. Manaus: OMP EDITORA, ISBN 978-85-62240-01-0.
Pérez, O. \& Morales, F. 2002. La táctica como instrumento de mejora de lavelocidad de reacción em los deportes de combate. Disponível em: <www.efdeportes.com>. Acesso em: jun. 2019.

Pinto, A.; Nogueira, J.; Villani, P. \& Alvarez, S. 2008. 44 Projeto preliminar: Levantamento de requisitos e proposta de um planejamento estratégico transparente e participativo para o IFSC. Disponível em: $<$ http:/qualidade.ifsc.usp.br/arquivos/Projeto Planejamento_Estrategico.pdf.>. Acesso em: jun. 2019.

Platonov, V. \&Bulatova, M. 2003. A preparação Física. Rio de Janeiro: Editora Sprint.

Platonov, V. N. 2008. Tratado Geral de Treinamento Desportivo. São Paulo: Editora Shape.

Quesada, J. 2007. Reflexiones sobre lapreparación táctica del boxeador. Disponível em: <www. efdeportes.com>. Acesso em: jun. 2019.

Quesada, R. 2008. La Preparacion técnico-tactica em elentrenamientodeportivo. Disponível em: $<$ www.boxeomania.com>. Acesso em: jun. 2019.

Quesada, R. 2008. Unanalisisdidacticodelentrenamiento diário enelboxeoprofesional. Disponível em: $<$ www.boxeomania.com>. Acesso em: jun. 2019.

Rooney, M. 2004. Training for Warriors: the team Renzo Gracie workout. 1.a Edição. New Jersey: Publicadopeloautor.

Rooney, M. 2006. Strategy is an Art. Disponivel em: <www.graciemag.com> versão em inglês. Acessoem: jun. 2019.

Rowe, C.; Harris, J. \& Roberts, S. 2006. Sporting con- tests: Seeing red? Puttingsportswear in context. Nature, v. 441, n.7090, p.3.

Tacollini, F.; Ferreira, C.; Anjos, F.; Ferreira, A. \& Costa, F. 2005. Composição Corporal de Jovens Pra- ticantes de JiuJítsu do Gênero Masculino pelo Somatotipo de HeathCarter. Revista cientifica anuário do LAFIEX, a.II, n.2.

Tubino, M. J. G. \& Moreira, S. B. 2003. Metodologia Cientifica do Treinamento Desportivo. $13^{\mathrm{a}}$ edição. Rio de Janeiro: Editora Shape.

Vecchio, Fabrício Boscolo Del, 2019. Hiit: como dominar a prescrição do treinamento intervalado de alta intensidade. $2^{\mathrm{a}}$ ed. Manaus -AM: OMP Editora.

Wilmore, J. H. \&Costill, D. L. 2001. Fisiologia do esporte e do exercício. 2.a edição. Barueri: Editora Manole. 